\title{
LITERASI INFORMASI MEDIA: Studi Kasus Manfaat Media Massa Terhadap Difusi Inovasi Pertanian di Kecamatan Singaparna Kabupaten Tasikmalaya
}

\author{
Oleh : Lilis Puspitasari ,Hanny Hafiar, Rully Khairul Anwar \\ Program Studi Humas \\ Universitas Padjadjaran
}

\begin{abstract}
Conseling is an advanced activity of information dispersion aims to change the society's attitude and behavior so as to accept and apply new ideas that have been presented. Changes in attitudes and behaviors of farmers in adopting innovation delivered is expected to improve the farmers' ability so that the quality and quantity of production increase, which in turn help to improve their living standards. In addition, an innovation can be accepted by the society through several stages: awareness, interest, evaluation, trial, and adoption.

Keywords: mass media, innovation diffusion, counseling

Abstrak

Penyuluhan merupakan kegiatan lanjutan dari penyebaran informasi bertujuan untuk mengubah sikap dan perilaku masyarakat agar menerima dan menerapkan ide-ide baru yang telah disajikan. Perubahan sikap dan perilaku petani dalam mengadopsi inovasi yang disampaikan diharapkan dapat meningkatkan kemampuan petani sehingga kualitas dan kuantitas peningkatan produksi, yang pada gilirannya membantu untuk meningkatkan standar hidup mereka. Selain itu, inovasi dapat diterima oleh masyarakat melalui beberapa tahap: kesadaran, minat, evaluasi, percobaan, dan adopsi.

Kata kunci: media massa, difusi inovasi, konseling
\end{abstract}

A. PENDAHULUAN bad 21 sering disebut-sebut
bebagai era informasi yang

informasi dari mancanegara begitu

gencar masuk ke atmosfir Indonesia.

Kejadian seperti ini mempunyai implikasi terhadap pola hidup masyarakat Indonesia. Dengan adanya antena parabola misalnya masyarakat dapat dengan mudah menyaksikan, menerima dan mengolah informasi dari mancanegara. Demikian juga akhir- 
akhir ini pemakaian internet di kotakota besar menambah arus informasi dari luar tidak dapat dipungkiri lagi keberadaannya. Masyarakat indonesia sudah dihadapkan kepada dunia serba capat tanpa melihat letak geografisnya.

Di sisi lain masyarakat Indonesia, khususnya masyarakat yang berada di perdesaan relatif sudah banyak memiliki media komunikasi seperti radio, tv maupun yang berlangganan majalah dan surat kabar. Media-media komunikasi ini sudah menjadi kelengkapan rumah tangga. Hal ini disebabkan peralatan media komunikasi tersebut relatif murah sehingga masyarakat terjangkau untuk memilikinya.

Selain arus informasi dari mancanegara, masyarakat Tasikmalaya dihadapkan kepada berbagai pilihan media massa, baik media massa elektronik (radio dan tv) maupun media massa cetak (surat kabar dan majalah). Kondisi seperti ini membuka peluang yang besar kepada masyarakat untuk memilih informasi yang beragam dari berbagai saluran.

Dalam realitas masayarakat, informasi tidak lagi dimonopoli para pamong, pemuka masyarakat, dan guru tetapi informasi sudah bervariasi baik cara penyampaiannya maupun sumbernya. Masyarakat dengan mudah sekali memiliki saluran komunikasi informasi, baik informasi faktual, maupun informasi yang sensasional.

Terpaan media massa ini dalam masyarakat Tasikmalaya intensitasnya telah begitu tinggi. Masyarakat Tasikmalaya yang memiliki radio dengan mudah mendapatkan informasi dari RRI. Disamping RRI, masyarakat Singaparna juga mempunyai akses ke radio-radio swasta lainnya yang ada di Kota singaparna.

Sedangkan bagi masyarakat yang memiliki TV dihadapkan kepada pilihan yang beragam pula. 
EduLib, Vol 1, No.1 Mei 2014

Masyarakat dengan mudah destruktif terhadap pembangunan mendapatkan siaran dari TVRI individu maupun masyarakat dapat Stasiun Semarang maupun pusat. bersifat massal dan cepat sampai Disisi lain siaran TV Swasta seperti kepada khalayak (masyarakat). RCTI, TPI, SCTV, ANTV, Trans TV, kecepatan informasi yang TV 7 dan Indoseiar dengan mudah disampaiakan berbagai media perlu bisa disaksikan masyarakat Tasikmalaya.

Dalam media massa cetakpun, masyarakat Tasikmalaya dihadapkan kepada berbagai surat kabar dan majalah, maupun yang terbit di Ibukota Propinsi dan Jakarta. Adapun surat kabar yang terbit di Ibukota Propinsi dan yang beredar di Tasikmalaya adalah suara Merdeka, Pikiran Rakyat, Mitra Desa dan Tabloid Hikmah ( erbit di Bandung). Keaadaan ini ditambah dengan hadirnya media massa dari ibukota seperti Surat kabar Kompas, Republika, Suara Karya dan berbagai majalah dan tabloid.

Dalam sistem informasi (penyampaian pesan) seperti di atas, dimungkinkan penyampaian yang bersifat konstruktif maupun 
dan selektif memilih acara dan pesanpesan yang disampaikan media massa. Kepekaan masyarakat dalam meimilih program media massa urgen utnuk mewujudkan masyarakat informatif.

Secara ideal media massa di Indonesia dalam eksistensinya harus konstruktif tidak desktruktif terhadap pembangunan diri dan masyarakat Indonesia khususnya para petani. Siaran yang konstruktif adalah siaran atau berita yang mendukung pembangunan diri dan masyarakat untuk bepikir dan berdzikir.

Masyarakat berpikir adalah masyarakat yang menggunkan akal pikirannya sehingga bertambah dewasa, maju dan penuh inovasi. begitu pula media elektronik dan cetak berfungsi membentuk masyarakat yang berzikir artinya masyarakat yang dijadikan objek pemasaran penjualan pesan dan iklan tidak menambah asing dengan eksistensi Tuhannya.
Untuk mewujudkan masyarakat seperti di atas, para pengelola media massa harus berpikir bukan hanya untung rugi secara materi, tetapi untung secara moril masyarakat sangat urgen dipertimbangkan. Para insan pers harus memperhitungkan keuntungan dan kerugiannnya bagi masyarakat yang tinggal di desa maupun kota.

Masyarakat kota dan desa yang aktif mencari dan selektif memilih informasi diperlukan dalam era informasi yang global. Hal ini dikarenakan masyarakat kota dan desa masih ada perbedaaan dalam meraih peluang informasi. Kondisi ini dilatarbelakangi oleh pekerjaan. Sektor industri dan jasa membutuhkan informasi yang relatif cepat. sedangkan masyarakat desa yang pekerjaannya relatif homogen dalam bidang pertanian relatif masih kurang memanfaatkan informasi dalam pekerjaan. 
EduLib, Vol 1, No.1 Mei 2014

Dari sektor pertanian pada umumnya dikerjakan oleh mereka yang berpendidikan menengah ke bawah. Sangat jarang mereka yang berpendidikan menengah dan tinggi terjun sendiri menekuni bidang pertanian secara langsung. para lulusan pendidikan menengah lebih tertarik bekerja atau mencari pekerjaan diluar sektor pertanian.

Realitas di atas disebabkan oleh beberapa hal anatra lain; pertama daya tarik untuk mengeolah pertanian sebagai profesi relatif kurang dibandingkan dengan sektor industri jasa dan perdagangan. Keuntungan komparatif secara finanasial sektor pertanian kurang kuat dibandingkan sektor lain. Generasi penerus para petani yang memilih menjadi petani karena di sektor lain tidak mendapatkan kesempoatan. menjadi petani atau buruh tani sebagai status pekerjaannya hanya dikarenankan alternatif terakhir.

Kedua, kepemilikan tanah pertanian di pulau jawa sudah tidak mempunyai daya dukung untuk pengembangan sektor pertanian ecara ekstensifikasi. Sehingga secara makro petani di Pulau Jawa sangat sedikit yang mempunyai tanah garapan yang menjadi hak miliknya di atas satu hektar. Survai dilapangan memebrikan gambaran kebanyakan petani menggarap sawah pertanian di bawah 0,5 ha. Hal ini lebih berkurang lagi manakala alih generasi dari orang tua kepada anaknya. Kepemilikan tanah akan sangat menyempit. Generasi muda yang berpenidikan menengah-tinggi melihat aset di bidang pertanian tidak lagi menjajikan untuk hidup di masa yang akan datang. Maka mereka lebih menyukai pekerjaan di sektor lain misalnya di perusahaan-perusahaan jasa maupun industri yang memiliki aset dan omset perusahaanya lebih menjajikan. Generasi muda anak petani lebih menyukai aset dan omset yang dimiliki oleh perusahaan orang lain secara riilnya sebagai tenaga buruh. 
Ketiga, kewirausahaan di sektor pertanian yang ada didesa-desa belum berkembang. Petani mengolah lahan pertanian masih bersifat tradisional. Kreativitas dalam diversifikasi pertanian kurang dimiliki para petani. agribisnis di perdesaan belum optimal dilakukan para petani.

Keempat, kebijakan atau kemauan politik pemerintah terhadap sektor pertanian tidak sungguhsunggu. Kebijakan secara makro belum tensu menguntungkan para petani yang menjadipelaksana dilapangan. Kebijakan pemerintah mengenai pertanian seringkali para petani gurem mengeluh betapa bertambah berat biaya penolahan pertanian.

Jadi permasalahan sumber daya manusia, kepemilikan tanah yang relatif sempit dan kewierausahaan petani belum optimal perkembangannya, membuat negara Indonesia yang agraris sangat rentan sekali terhadap situasi dari luar.
Swasembada beras, kedelai puluhan tahun digembargemborkan. secara riil para petani dijadikan objek untuk prestise penguasa yang bersifat kepentingan sendiri. Kemauan politik pemerintah dalam bidang pertanian belum menyentuh para petani yang ada di perdesaan. Kebijakan pertanian lebih menguntungkan plaku ekonomi dibidang pertanian.

Permaasalahan di bidang pertanian menyangkut hajat hidup orang banyak (para petani). Untuk itu diperlukan sesuatu perubahan yang mengarah ke hal yang baru (inovasi) yang dapat mengatasi permaslahan di bnjdang pertanian. sesuatu yang mengarah kepada perubahan ini perlu disosialisikan kepada masyarakat secara komprehensi. Masyarakat petani diberdayakan sehingga menjadi masyarakat berpikir. Sosialisasi inovasi agar para petanidengan notabenenya banyak kelemahan akan mengerti akan peranannya. Untuk menuju perbaikan 
EduLib, Vol 1, No.1 Mei 2014

pada sektor pertanian sosialisai ke semua sistem yang ada dimasyarakat tentang ide-ide, gagasan-gagasan, penemuan-penemuaan bartu dibidang pertanian maupun kebijakan pemerintah (difusi) secara optimal.

Optimalisasi penyebaran ideide, gagasan-gagasan, penemuanpenemuan dan kebijakan di bidang pertanian harus menggunakan berbagai saluran dan bentuk komunikasi kemasyarakat. keseriusan untuk mencapai atau minimalisasi permaslahan di bidang pertanian harus melibatkan seluruh komponen bangsa yang terlibat langsung maupun tidak langsung.

Dalam era informasi dan melihat keberhasilan program Keluarga Berencana dalam menekan angka pertumbuhan penduduk di Indonesia perlu dijadikan sebuah contoh bagaimana program nasional yang dilakukan secara kesinambungan dan ada kemauan politik dari pemerintah. Program mengentaskan petani miskin harus diupayakan secara struktural pemerintahan maupun mengubah pola pikir dan para petani secara berkelanjutan. Petani harus mempunyai kesempatan untuk meningkatkan kesejahteraannya.

Globalisasi dalam bidang perdagangan akan menantang kemampuan dan daya uji petani di masa yang akan datang. Untuk mensosialisasikan ide-ide, gagasangagasan atau penemuan-penemuan dibidang pertanian perlu dan urgen diketahui masyarakat petani secara cepat dan serentak. Untuk mencapai kuantitas petani yang begitu luas sebaran tempat tinggalnya diperlukan peranan media massa yang optimal.

Media massa harus bertanggung jawab atas penyebaran ide-ide, penemuan-penemuan baru maupun kebijakan-kebijakan pemerintah di bidang pertanian. Informasi tentang penemuan-penemuan baru yang mengarah keperbaikan kesejahteraan petani perlu dianggap yang urgen oleh para insan pers. 
Kontrol sosial yang diperankan media massa perlu direalisasikan terhadap kebijakan pemerintah atau kebijaksaan pejabat baik pusat maupun daerah yang merugikan pra petani baik jangka pendek maupun jangka panjang. Kepedulian media massa terhadap ketidakadilan yang menimpa para petani harus dipublikasikan terus menerus.

\section{B. PEMBAHASAN}

\section{Metodologi}

a. Metode Penelitian

Metode penelitian yang peneliti pergunakan dalam penelitian ini adalah metode deskriptif kualitatif sehingga peneliti tidak hanya menggali data-data yang tampak berupa angka-angka seperti halnya pada metode kuantitatif, tetapi juga menginterpretasikan data dan mencari hal-hal dibalik data disertai dengan teori-teori yang mendukung. b. Lokasi penelitian

Penelitian ini dilaksanakan di Kecamatan Cineam Kabupaten Tasikmalaya.

c. Sasaran penelitian

Sasaran dari penelitian ini adalah petani salak yang berasa di Kecamatan Cineam Kabupaten Tasikmalaya.

d. Teknik Pemilihan Informan

Teknik pengambilan sampel yang akan digunakan dalam penelitian ini adalah Stratified Random Sampling dimana petani salak di Kecamatan Cineam Kabupaten Tasikmalaya.

e. Teknik Pengumpulan Data Untuk memperoleh data bagi penelitian ini digunakan tiga teknik pengumpulan data, yakni: wawancara, observasi, dan dokumentasi. 
EduLib, Vol 1, No.1 Mei 2014

f. Jenis Data

Data Primer, diperoleh dari wawancara yang dilakukan dengan key person, informan, serta observasi lapangan.

g. Data Sekunder, Diperoleh dari arsip, dokumen dan literatur yang sesuai dengan topik dari penelitian ini

h. Analisa data

Teknik analisa data yang digunakan dalam penelitian ini adalah metode interaktif yang terdiri dari reduksi data, penyajian data, dan penarikan kesimpulan yang dilakukan dalam bentuk interaktif dengan proses pengumpulan data sebagai suatu siklus (Mills dan Huberman, 1992)

i. Validitas data Validitas data dalam penelitian ini akan diukur melalui triangulasi data, yakni teknik pemeriksaan keabsahan data yang memanfaatkan sesuatu yang lain di luar data itu untuk keperluan pengecekan atau sebagai pembanding terhadap data tersebut. Triangulasi data meliputi triangulasi sumber, peneliti, metode, dan teori (Moleong, 2001)

j. Hasil dan Pembahasan

Seperti halnya daerahdaerah lain di Indonesia, Kecamatan Singaparna juga sedang giat melaksanakan program-program

pembangunan, baik yang bersifat fisik maupun non fisik. Pembangunan fisik yang dilaksanakan adalah pembangunan gedung SD, polindes, pengaspalan jalan, jembatan, dan masjid. Sementara untuk pembangunan non fisik berupa pembentukan media bagi masyarakat untuk dapat mengakses informasi 
mengenai kesehatan, pendidikan, pertanian, rohani melalui program-program penyuluhan dan pengajian.

Untuk menambah pengetahuan masyarakat dan mensosialisasikan programprogram atau kebijakankebijakan baru, diadakan penyuluhan (di tingkat RW dengan pembicara dari kecamatan ataupun dari media massa) meskipun frekuensi pertemuannya sangat sedikit. Penyuluhan merupakan bentuk pendidikan informal untuk mendidik masyarakat agar menjadi tahu dan dapat menyelesaikan masalahnya sendiri. Penyuluhan adalah suatu sistem pendidikan dengan percontohan. Tujuan penyuluhan adalah untuk meningkatkan kesejahteraan, kemakmuran petani dengan program modernisasi pertanian sehingga tercipta perubahan sikap mental dan cara bekerja melalui kombinasi belajar sambil berbuat sehingga masyarakat terangsang untuk meniru dan peningatan ketrampilan dapat terbina karena disertai contohcontoh nyata (Assegaff, 1987)

Kredibilitas komunikator (kadar keterpercayaan pernyataan-pernyataan pengirim di telinga komunikan) menjadi aspek yang menentukan untuk terciptanya komunikasi yang efektif, sehingga harus ada kesesuaian antara materi yang disampaikan dengan latar belakang komunikator, misalnya dapat dipercaya, mempunyai motivasi yang baik, bersahabat, kesesuaian antar keahlian dengan materi, dan dinamis (Johnson, 1994). Selain aspek kredibilitas, perlu 
EduLib, Vol 1, No.1 Mei 2014

pula diusahakan agar pesan yang disampaikan mudah dipahami serta mendapatkan umpan balik secara optimal tentang pengaruh pesan dalam diri penerima (Supratiknya, 1995)

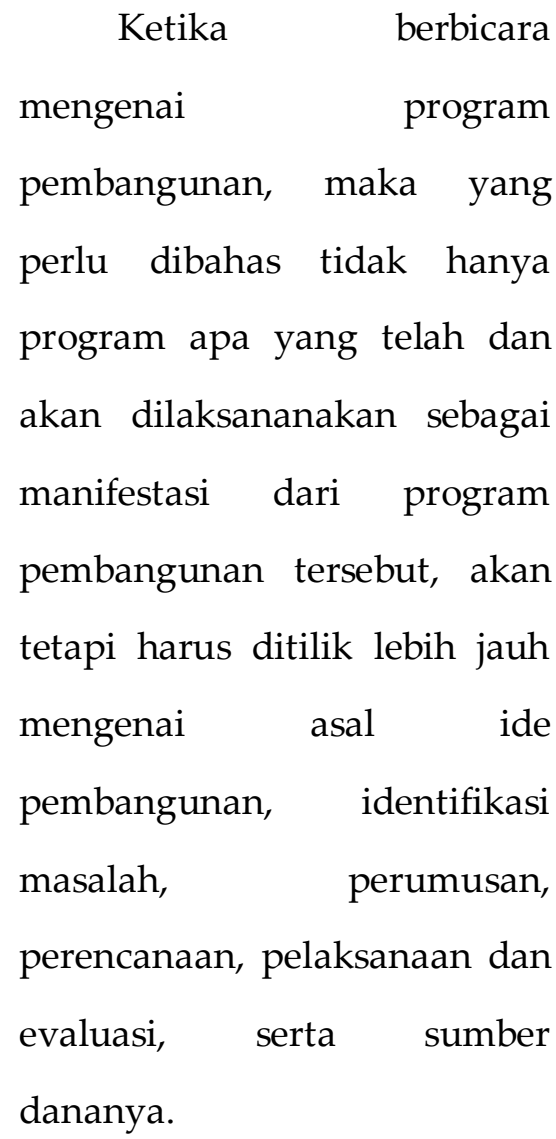

Dari data yang diperoleh dapat diketahui bahwa peran serta warga dalam proses pembangunan di Kecamatan Cineam berupa pemunculan ide-ide pembangunan yang perlu dilaksanakan di desa tersebut. Hal itu menunjukkan tumbuhnya kesadaran dan kepekaan dari masyarakat mengenai lingkungannya. Partisipasi mempunyai prinsip utama kerjasama komunitas dan pertumbuhan pribadi (community participation and personal growth). Sehingga partisipasi berfokus lebih pada pengalaman keikutsertaan sebagai seseorang yang sederajat dalam proses berbagi pengetahuan atau kemampuan (Nasution, 1988).

$$
\text { Kleijans }
$$

(dalam

Nasution, 2002) berpendapat bahwa pada akhirnya bukanlah soal teknologi atau GNP, tetapi peningkatan pengetahuan dan ketrampilan baru, tumbuhnya suatu kesadaran baru, perluasan wawasan manusia, meningkatnya wawasan 
manusia, meningkatnya semangat kemanusiaan, dan suntikan kepercayaan diri.

Selain penggalian ideide, pelaksanaan suatu program pembangunan memerlukan tahapan lain yang tidak kalah pentingnya seperti yang termuat dalam disain instruksional sebagai salah satu desain dalam strategi komunikasi pembangunan. Desain ini memfokuskan pada pembelajaran individuindividu yang dituju sebagai suatu sasaran yang fundamental. Tahapantahapan yang tercakup dalam desain ini adalah perencanaan, implementasi, evaluasi (Nasution, 1988)

Selain pemunculan ide, identifikasi masalah, pembahasan permasalahanpermasalahan yang ada di daerah tersebut,. Membuat warga semata-mata bukan hanya menjadi obyek pembangunan, tetapi juga subyek pembangunan. Partisipasi warga tersebut bahkan juga sampai pada tahap pelaksanaan dan evaluasinya.

\section{Pembahasan}

a. Akseptabilitas Para Petani Terhadap Informasi Mengenai Pertanian Dari Media Massa Media massa merupakan kekuatan dalam menyebarkan informasi yang dapat menjangkau berbagai lapisan sosial. Dengan posisinya sebagai entitas yang dapat meningkatkan pengetahuan dan wawasan, media massa dimanfaatkan untuk menjaga dan mengelola lingkungan terutama dalam hal ini pertanian, melalui pemberitaan yang menarik khalayak. 
EduLib, Vol 1, No.1 Mei 2014

\begin{tabular}{|c|c|}
\hline Media & diferensiasi, \\
\hline mengalami & kebaruan. \\
\hline perkembangan yang dinamis & Eksistensi media yang \\
\hline sejak reformasi politik. & dapat menyebarkan \\
\hline Sebelum masa tersebut, media & khalayak \\
\hline cenderung dipakai sebagai & dimanfaatkan \\
\hline instrumen politik pemerintah & menyadarkan \\
\hline dalam menyebarkan kebijakan & terhadap pentingnya informasi \\
\hline publik. Media tidak mandiri & pertanian untuk kesejahteraan \\
\hline dan wajib menjalankan tugas & manusia. Melalui pemberitaan, \\
\hline pembangunan dengan & kampanye publik, \\
\hline pengendalian yang ketat dari & layanan masyarakat, \\
\hline kekuasaan negara. & propaganda, \\
\hline Media massa tetap harus & diharapkan mampu berperan \\
\hline menjaga keseimbangan, antara & dalam menjaga keseimbangan \\
\hline kepentingan bisnis dan & alam, lingkungan \\
\hline idealisme dalam memberikan & ekonomi dan politik yang \\
\hline informasi kepada masyarakat, & berkembang dalam \\
\hline meningkatkan & kawasan. \\
\hline wawasan. Senada dengan & Hakikatnya, \\
\hline pernyataan itu, Eastman dan & kekuatan \\
\hline$(2006: 19)$ & komunikasinya, harus berjalan \\
\hline menyatakan, program siaran & seiring dengan program \\
\hline harus dikaitkan dengan & pemeliharaan \\
\hline kebiasaan khalayak, biaya & Beberapa hal yang perlu \\
\hline kompatibilitas, & didukung oleh media massa \\
\hline ketersediaan & dalam penegakan peraturan \\
\hline
\end{tabular}


lingkungan antara lain adalah (1) Masyarakat berhak memperoleh pengetahuan tentang lingkungan hidup yang baik dan sehat. (2) Setiap orang berhak mengajukan usul dan/atau keberatan terhadap rencana usaha dan/atau kegiatan yang diperkirakan dapat menimbulkan dampak terhadap lingkungan hidup, (3) Setiap orang berhak untuk berperan dalam perlindungan dan pengelolaan lingkungan hidup sesuai dengan peraturan perundang-undangan,

Setiap orang berhak melakukan pengaduan akibat dugaan pencemaran dan/atau perusakan lingkungan hidup.

Media massa memiliki sejumlah kelebihan dalam penyebaran informasi yang ditujukan kepada khalayak luas. Namun permasalahannya, pemanfaatan media untuk kepentingan pemeliharaan lingkungan, sangat bergantung kepada gerak laju media, yang dipengaruhi oleh kondisi negara, dan aneka peraturan kelembagaan, fungsi pemberitaan, penyiaran dan aspek lain yang berkaitan dengan orientasi media.

b. Kontribusi Informasi dari Media Massa Terhadap Pengetahuan Para Petani Untuk Menggarap Lahan Pertaniannya Secara Optimal

Seperti kita ketahui bersama, Indonesia merupakan salah satu negara berkembang yang mayoritas penduduknya menggantungkan hidupnya pada tanah-tanah pertanian dengan cara berpikir dan latar belakang pengetahuan pertanian yang kebanyakan masih sangat tradisional sehingga terkadang sulit 
EduLib, Vol 1, No.1 Mei 2014

mengubah pandangan mereka

untuk memakai atau

menerapkan cara-cara ataupun

ide-ide baru yang jauh lebih

produktif. Dengan demikian,

kualitas maupun kuantitas

produk pertanian belum dapat

diperoleh secara maksimal.

Padahal dengan sumber daya

tanah yang subur dan luas

memungkinkan Indonesia

dapat menjadi negara

penghasil pertanian yang

sangat besar.

Oleh karena itu, untuk meningkatkan kualitas

maupun kuantitas hasil pertanian dan juga

pengetahuan petani

diperlukan suatu

upaya/aktifitas yang dirasa

mampu menjadi jembatan

penghubung antara petani

dengan para ahli di bidang

pertanian dengan temuan-

temuan terbaru mereka,

sehingga diharapkan kendala-

kendala yang selama ini

dialami para petani dapat

diminimalkan. Salah satu

upaya yang dimaksud di sini

adalah penyuluhan. Adapun

isi pesan penyuluhan adalah

sebagai berikut: 
Bagan 1. Pesan Penyuluhan

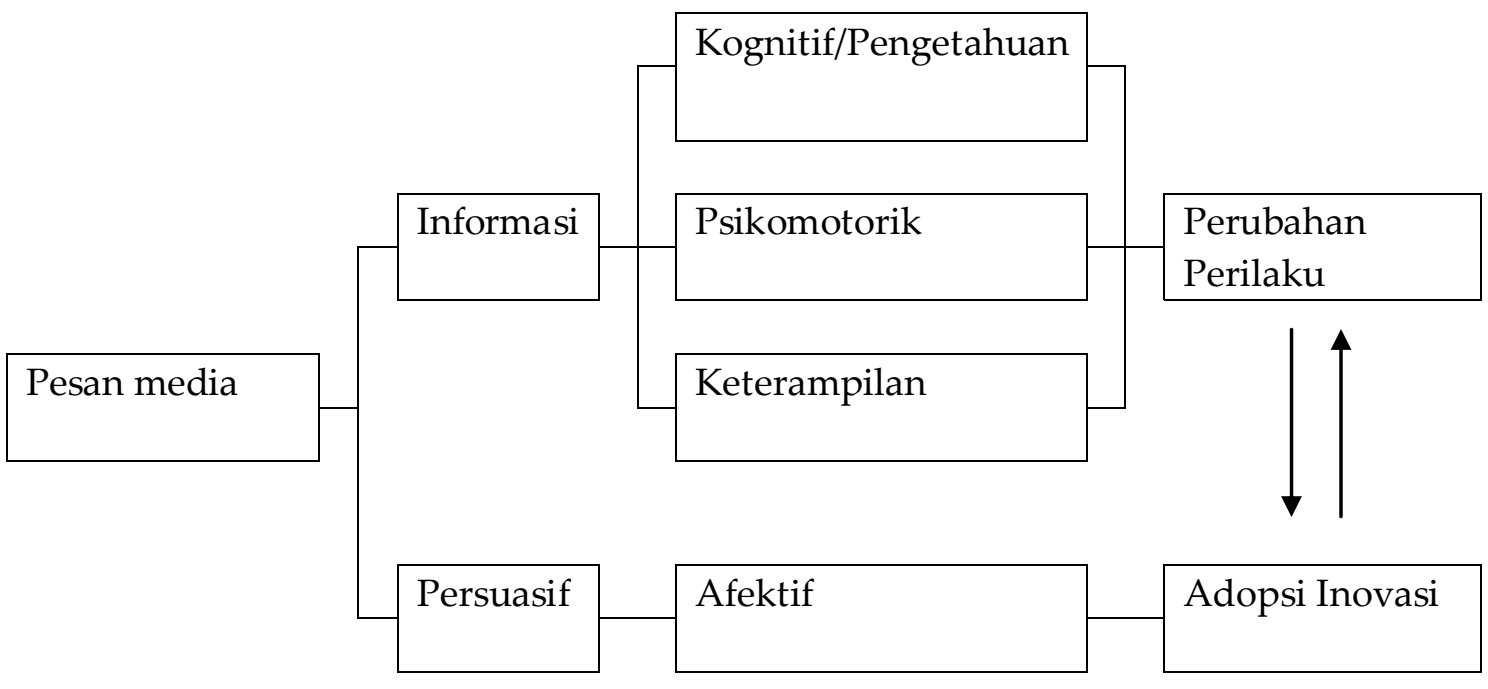

Pesan media merupakan . aktifitas lanjutan dari penerangan, yang tujuannya adalah meningkatkan kesejahteraan masrakat pedesaan. Secara lebih rinci tujuan dari penyuluhan adalah sebagai berikut:

1) Informatif, yaitu tujuan untuk memberikan informasi yang menggunakan pendekatan pada pikiran. Jika kita berkomunikasi secara informatif, maka informasi yang kita sampaikan harus faktual dan objektif, terutama masalah sedang dihadapi oleh para petani.

2) Persuasif, bertujuan untuk menggugah perasaan penerima. Tujuan ini lebih menggunakan pendekatan emosi, bukan pikiran.

3) Entertaintment (menghibur)

4) Mengubah perilaku (sikap, pengetahuan, ketrampilan) dan meningkatkan sikap positif terhadap setiap paket pembangunan.

5) Meningkatkan kemampuan para petani di desa untuk 
EduLib, Vol 1, No. 1 Mei 2014

$\begin{array}{lrr}\text { mengembangkan } & \text { usaha } \\ \text { secara } & \text { efisien di } & \text { bidang } \\ \text { usaha } & \text { yang } & \text { dapat }\end{array}$

memberikan manfaat dalam

batas waktu yang

diinginkan.

6) Meningkatkan pendapatan

masyarakat desa beserta

keluarganya sekaligus

mampu meningkatkan

kesejahteraan sosial.

7) Mewujudkan partisipasi

aktif masyarakat desa

dalam pembangunan

(Levis, 1996).

Penyuluhan sebagai

aktifitas lanjut dari

penerangan bertujuan

untuk mengubah perilaku

(sikap, pengetahuan dan

ketrampilan) petani.

Memang mengubah

perilaku seseorang bukan

pekerjaan yang mudah.

Oleh karena itu diperlukan

suatu upaya untuk

mewujudkan komunikasi

yang efektif.
Komunikasi efektif akan tercipta apabila kita memperhatikan beberapa unsur yang mempengaruhinya, yakni:
a) Empati
b) Positiveness
c) Keterbukaan
d) Dukungan
e) Kesamaan

Perubahan perilaku para petani akan tercipta ketika para petani atau masyarakat menerima dan menerapkan inovasi yang dikomunikasikan penyuluh atau sumber informasi. Dengan demikian para penyuluh para penyuluh harus memiliki kemampuan mempengaruhi orang yang tinggi sehingga petani akan memberikan tanggapan seperti yang kita harapkan yakni mau menerima dan menggunakan inovasi yang kita sampaikan. 
Tabel 1

Faktor-faktor yang mempengaruhi tahap adopsi-inovasi

\begin{tabular}{|c|c|c|}
\hline $\begin{array}{l}\text { TAHAPAN } \\
\text { ADOPSI }\end{array}$ & FAKTOR PRIBADI & FAKTOR LINGKUNGAN \\
\hline 1. Kesadaran & $\begin{array}{l}\text { kontak dengan sumber-sumber } \\
\text { informasi di luar masyarakat }\end{array}$ & 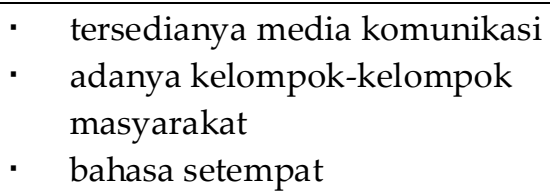 \\
\hline 2. Minat & $\begin{array}{ll}\text { - } & \text { tingkat kebutuhan } \\
\text { - } & \text { kontak dengan sumber } \\
\text { informasi } \\
\text { - } \quad \text { keaktifan mencari sumber } \\
\text { informasi }\end{array}$ & 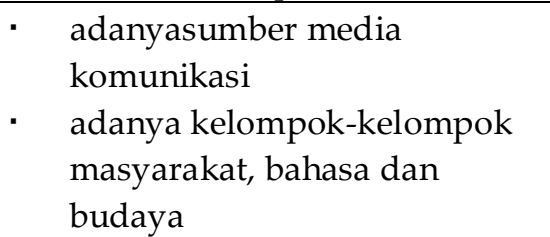 \\
\hline 3. Penilaian & $\begin{array}{l}\text { pengetahuan tentang } \\
\text { keuntungan relatif } \\
\text {. } \quad \text { tujuan dari usaha taninya }\end{array}$ & $\begin{array}{l}\text { penerapan tentang } \\
\text { keuntungan relatif } \\
\text { pengalaman petani lainnya }\end{array}$ \\
\hline 4. Mencoba & $\begin{array}{ll}\text { - } & \text { ketrampilan spesifik } \\
\text { - } & \text { kepuasan pada cara-cara lama } \\
\text { keberanian menanggung } \\
\text { resiko }\end{array}$ & $\begin{array}{l}\text { - } \text { penyuluhan tentang cara } \\
\text { praktek } \\
\text { - faktor-faktor alam } \\
\text { - faktor-faktor harga }\end{array}$ \\
\hline $\begin{array}{l}5 . \\
\text { Menerapkan }\end{array}$ & $\begin{array}{l}\text { kepuasan pada cara atau } \\
\text { pengalaman I } \\
\text { kemampuan mengelola } \\
\text { dengan cara baru }\end{array}$ & $\begin{array}{l}\text { analisis keberhasilan - } \\
\text { kegagalan } \\
\text { tujuan dan minat keluarga }\end{array}$ \\
\hline
\end{tabular}

\section{Sumber: Margono (1978)}

Dengan demikian dapat sehingga dapat mengembangkan dikatakan bahwa peranan kepcayaan petani bahwa penyuluh penyuluhan dalam usaha benar-benar mau dan mampu memperlancar proses difusi-inovasi membantu petani, c) mendiagnosis adalah a) menumbuhkan kebutuhan untuk berubah, dengan menunjukkan kelemahan-kelemahan mereka serta menumbuhkan kebutuhan berubah menuju kondisi yang diinginkan, b) membangun hubungan yang semakin erat antara petani dengan penyuluh segala permasalahan yang dihadapi petani, d) menumbuhkan keinginankeinginan petani menjadi tindakan yang nyata, e) menumbuhkan keinginan yang belum terpikir sebelumnya, f) memperkokoh perubahan yang telah terjadi sehingga 
EduLib, Vol 1, No.1 Mei 2014

memungkinkan adanya tindak lanjut,

g) meningkatkan kemandirian petani (Lenis, 1996).

\section{Daftar Pustaka}

Arikunto, Suharsimi. (1998). Prosedur

Penelitian, Suatu Pendekatan Praktek (Edisi Revisi II), Cetakan XI, PT. Rineka Cipta, Jakarta

Blake, H. Reed \& Edwin O. Haroldsen, (2003). Taksonomi Ilmu Komunikasi, Papyrus,

Surabaya

Chambers, Robert, (1983). Rural Development: Putting the Last Firs, Pearson Education Ltd, Edinburg

Effendy, O.U., (1986). Human

Relatons dan Public Relations, CV. Mandar Maju, Bandung

Hanafi, Abdillah, (1987).

Memasyarakatkan Ide-Ide Baru, Usaha Nasional, Surabaya

Liliweri, Alo, (1991). Komunikasi Antar Pribadi, PT. Citra Aditya

Bakti, Bandung
Mills, M.B. Huberman, A. Michael. (1992). Analisis Data Kualitatif, UI Press, Jakarta

Moleong, L.J. (2001). Metodologi Penelitian Kualitatif, PT. Remaja Rosdakarya, Bandung

Jahi, Amri, 1988, Komunikasi Massa dan Pembangunan Pedesaan di Negara-Negara Dunia Ketiga, PT. Gramedia, Jakarta

Siregar, Amir Effendi, (1991). Arus Pemikiran Ekonomi Politik, Tiara Wacana, Yogyakarta Siregar, Ashadi, (1990). Komunikasi Sosial, BPP Fisip UGM, Yogyakarta

Supratiknya, A, (1995). Komunikasi Antar Pribadi, Tinjauan Psikologi, Kanisius, Yogyakarta 